\title{
More Doctors or Better Care?
}

\section{Plus de médecins ou de meilleurs soins?}

\author{
by DiANE E. WATSON, MBA, PHD \\ Centre for Health Services and Policy Research \\ University of British Columbia \\ Vancouver, BC \\ KIMBERLYN M. MCGRAIL, MPH, PHD \\ Centre for Health Services and Policy Research \\ University of British Columbia \\ Vancouver, BC
}

\begin{abstract}
The Canadian Medical Association's More Doctors, More Care campaign seeks to align physician supply targets with policy decisions elsewhere in the Organisation for Economic Co-operation and Development (OECD). Using OECD data for 19 countries to assess the relationship between physician supply and healthcare outcomes, we have determined that there is no association between avoidable mortality and overall physician supply. Similarly, there is no relationship between avoidable mortality and general practitioners and family physicians per capita, specialists per capita, nurses per capita, doctors and nurses per capita or health expenditures per capita. These findings should move us to recognize that (a) more doctors will not necessarily translate into better healthcare outcomes for Canadians and (b) it is in Canadians' better interests that we instead focus on realizing opportunities to improve access to high-quality care and to ensure that changes in physician turnover do not threaten the current generalist-to-specialist mix.
\end{abstract}




\section{Résumé}

La campagne de l'Association médicale canadienne «Plus de médecins pour plus de soins » vise à harmoniser les objectifs, en termes de disponibilité de médecins, aux décisions de politiques qu'on trouve ailleurs dans les pays de l'Organisation de coopération et de développement économiques (OCDE). Les données de 19 pays de l'OCDE ont servi à évaluer la relation entre la disponibilité de médecins et les résultats en santé. Nous avons déterminé qu'il n'y a pas de relation entre le taux de mortalité évitable et la disponibilité globale de médecins. De même, il n'y a pas de relation entre le taux de mortalité évitable et le nombre d'omnipraticiens ou de médecins de famille par personne, le nombre de spécialistes par personne, le nombre d'infirmières par personne, le nombre de médecins et d'infirmières par personne ou les dépenses pour la santé par personne. Ces résultats devraient nous porter à reconnaitre (a) que le fait d'avoir plus de médecins néquivaut pas nécessairement à de meilleurs résultats en termes de santé pour les Canadiens et (b) qu'il est plus favorable pour les Canadiens de mettre l'accent sur l'amélioration de l'accès à des services de haute qualité et de sassurer que le renouvellement des effectifs ne menace pas le ratio actuel d'omnipraticiens et de spécialistes.

I January 2008, the Canadian Medical Association (CMA) launched its More Doctors, More Care campaign "to put the growing doctor shortage on the federal political agenda." While campaigns promoting increases in the number of healthcare providers are not new, tying Canadian physician supply targets to policy decisions elsewhere in the Organisation for Economic Co-operation and Development (OECD) is.

According to the CMA (2008), "Canada would need 26,000 more doctors to meet the OECD average of doctors per population." But is this the right, or even a relevant, metric? If our objective is the pursuit of a high-performing healthcare system that is accessible, efficient and effective at protecting and promoting health, then surely healthcare outcomes ought to be the focus of attention and action.

We used OECD data to assess the degree to which healthcare outcomes are related to physician supply. Avoidable mortality is widely recognized as a valid healthcare outcome indicator and is used extensively in Australia, New Zealand and Europe to inform policy and practice (Nolte and McKee 2008). Avoidable mortality measures the extent of premature death (before age 75) from causes that should be avoidable through timely and effective healthcare, as identified through systematic reviews. Some examples include treatable cancers, maternal death and complications of common surgical procedures, epilepsy, bacterial infections and influenza. In 2002, avoidable mor- 
tality accounted for $22 \%$ of total premature mortality among males and $29 \%$ among females in Canada. Data were available for 19 countries (Nolte and McKee 2008).

The scatter plot in Figure 1 illustrates that there is no association between avoidable mortality and overall physician supply. Similar plots illustrate that there is also no relationship between avoidable mortality and (a) general practitioners and family physicians per capita, (b) specialists per capita, (c) nurses per capita, (d) doctors and nurses per capita or (d) health expenditures per capita, though the ordering of countries changes depending on which indicator is used (graphics available at www.chspr. ubc.ca).

FIGURE 1. Avoidable mortality by physician supply in 19 OECD countries, 2002

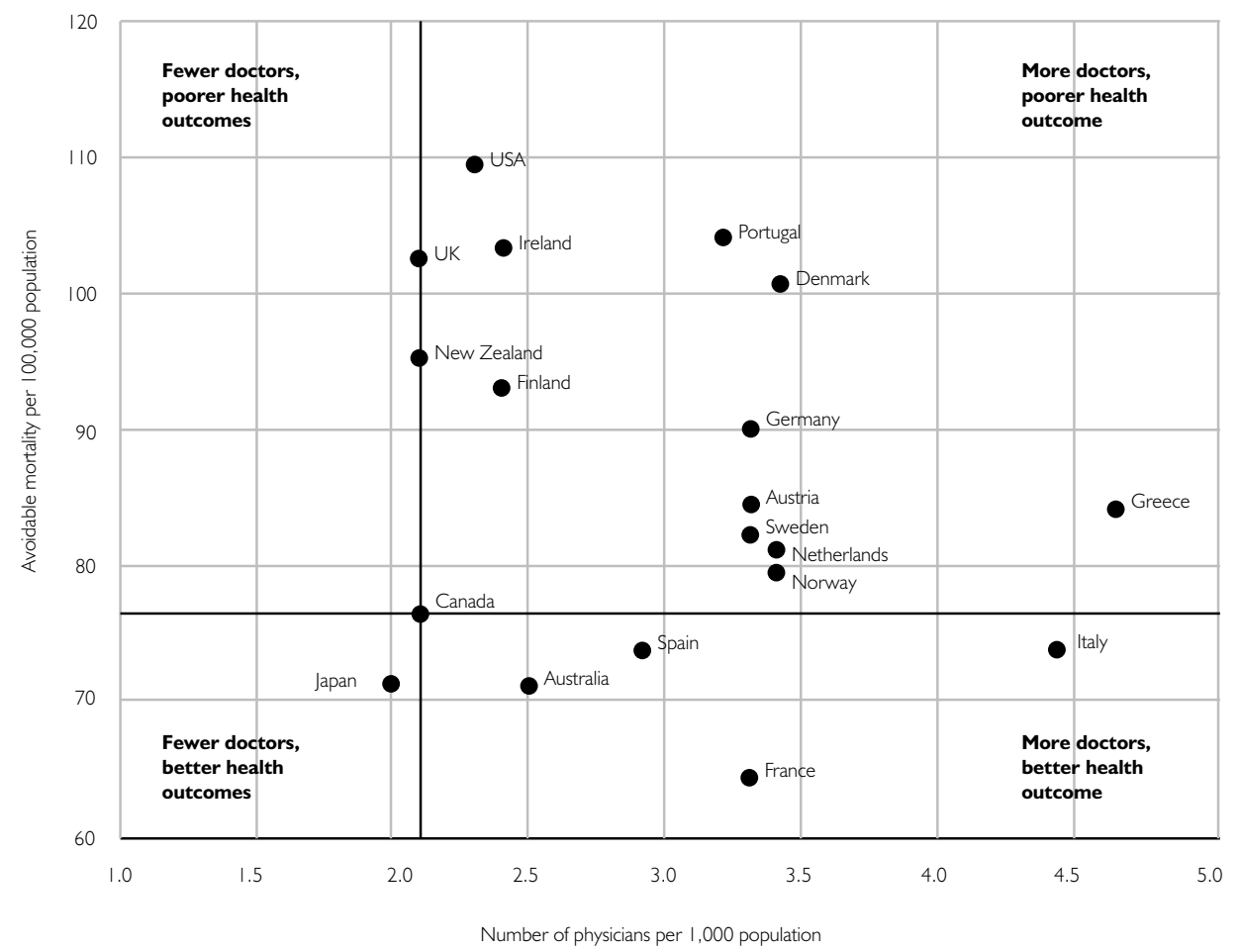

Source: Physician-to-population ratios from 2005 OECD Health Data for 2002/03. Avoidable mortality as reported by Nolte and McKee (2008).

The implication is that more doctors will not necessarily translate into better healthcare outcomes for Canadians. Most countries that have more physicians per capita have similar or worse healthcare outcomes than Canada. For example, Spain, Norway and Italy have more physicians per capita and similar outcomes. Portugal, Denmark, Germany and Greece have more physicians per capita and worse outcomes (Figure 1). All these countries also attain worse health outcomes using other OECD metrics (Or et al. 2005). 
Closer inspection of these OECD data illustrates that differences in healthcare outcomes for a specific level of supply (or vice versa) reflects variation in efficiency. The relative efficiency of Canada's physician supply is most evident when comparing it to that in the United Kingdom and New Zealand. Both these countries have the same number of physicians per capita, but far worse healthcare outcomes in terms of avoidable mortality (Figure 1).

Countries in the lower left quadrant of the figure use medical personnel most efficiently to attain the best healthcare outcomes. Japan's and Canada's positions in this quadrant are consistent with previous OECD analyses using other health outcomes, including life expectancy (at birth and age 65, female and male), infant mortality and potential years of life lost by heart disease (female and male) (Or et al. 2005).

International experience demonstrates that improvements in access and care processes can be attained without increasing physician-to-population ratios. Though there are no OECD data on patient experiences with physician care, there are international comparative studies on the topic that include countries with physician-to-population ratios similar to Canada's. Results suggest that adults in those countries have both shorter and longer wait times for appointments with primary care and specialist physicians, better and worse doctor-patient communication or care coordination and shorter and longer encounters with primary care doctors (Bindman et al. 2007; Schoen et al. 2005). There is no systematic relationship between physician supply and these metrics, even when three additional countries (France, Germany and the Netherlands) are added, all of which have physician-to-population ratios 1.5 times that of Canada (Schoen et al. 2009).

The Canadian physician-to-population ratio has been stable for over 20 years (Evans and McGrail 2008), and avoidable deaths declined between 1997 and 2002 (Nolte and McKee 2008), demonstrating that improvements in healthcare outcomes can be attained in this country without increasing the physician-to-population ratio. Taken together, the evidence suggests that there is no compelling reason to spend billions more dollars to increase our physician supply simply for the purpose of bringing our ratio more in line with the OECD average.

There are real physician supply issues that should motivate us to continue to focus policy attention on this area, such as increases in physician retirement rates, workload differences between younger physicians and older retirees (Watson et al. 2006), geographic variation in availability and shifts in demand for healthcare providers. But federal, provincial and territorial governments have already made significant investments to expand medical school enrolment and the supply of international medical graduates to ensure that more doctors enter practice at the same time that more retire. In the decade from $1997 / 98$ to $2007 / 08$, first-year enrolment rose by $59 \%$, from 1,577 to 2,506. Graduations should reach about 2,500 in 2011 (Evans and McGrail 2008). It takes time to create doctors, so we are only now starting to feel the effects of these 
public investments to put an unprecedented number of graduates from our medical schools into the workforce. It is by no means clear that further increases are required.

One of the possible reasons for Canada's achieving better health outcomes than many OECD countries may be our high generalist-to-specialist physician ratio. A rich supply of general practitioners and family physicians improves health outcomes, including all-cause, cancer, heart disease, stroke and infant mortality; low birth weight; life expectancy and self-rated health (Macinko et al. 2007; Pierard 2009). Analyses of OECD data by others (Macinko et al. 2003) support findings of international syntheses of evidence (Atun 2004; Starfield et al. 2005) that strong primary care systems not only improve population health but also reduce health disparities and buffer the health effects of socio-economic circumstances at lower cost than healthcare systems that rely more extensively on secondary and tertiary care. Conversely, areas with a higher concentration of specialists spend more but rate lower on quality and outcomes (Baicker and Chandra 2004). Areas in Canada with a higher concentration of family physicians have higher levels of health, while areas with a higher concentration of specialists have lower levels of health (Pierard 2009).

These data should inspire us to realize opportunities to improve access to better care and to ensure that increases in workforce turnover (more exits, more entrants) do not shift the current mix of generalist-to-specialist physicians, which is at risk of changing for the worse (Harvey et al. 2005). These efforts seem more in the interests of Canadians than the current CMA campaign to increase overall physician supply ratios to catch up with other OECD nations.

\section{ACKNOWLEDGEMENTS}

This work was funded, in part, by a Canadian Institutes of Health Research grant entitled "Anatomy of a Doctor Shortage." Watson is a Harkness alumna of the International Program in Policy and Practice at the Commonwealth Fund.

Correspondence may be directed to: Diane Watson, Centre for Health Services and Policy Research, 201 - 2206 East Mall, Vancouver, BC V6T 1Z3; e-mail: dwatson@chspr.ubc.ca.

\section{REFERENCES}

Atun, R. 2004. What Are the Advantages and Disadvantages of Restructuring a Health Care System to be More Focused on Primary Care Services? Copenhagen: WHO Regional Office for Europe.

Baicker, K. and A. Chandra. 2004. "Medicare Spending, the Physician Workforce, and Beneficiaries' Quality of Care." Health Affairs (Suppl.W4): 184-97. Retrieved May 22, 2009. $<$ http://content.healthaffairs.org/cgi/content/short/hlthaff.w4.184v1>. 
Bindman, A.B., C.B. Forrest, H. Britt, P. Crampton and A. Majeed. 2007 (June 16). "Diagnostic Scope of and Exposure to Primary Care Physicians in Australia, New Zealand, and the United States: Cross Sectional Analysis of Results from Three National Surveys." British Medical Journal 334(7606): 1261 .

Canadian Medical Association (CMA). 2008. “Canadian Medical Association Launches Major Campaign for More Doctors." Retrieved May 22, 2009. <http://www.cma.ca/index.cfm/ci_ id/55128/la_id/1.htm>.

Evans, R.G. and K.M. McGrail. 2008. "Richard III, Barer-Stoddart and the Daughter of Time." Healthcare Policy 3(3): 18-28.

Harvey, A., J.G. DesCoteaux and S. Banner. 2005."Trends in Disciplines Selected by Applicants in the Canadian Resident Matches, 1994-2004." Canadian Medical Association Journal 172: 737.

Macinko, J., B. Starfield and L.Y. Shi. 2003. “The Contribution of Primary Care Systems to Health Outcomes within Organisation for Economic Co-operation and Development (OECD) Countries, 1970-1998." Health Services Research 38(3): 831-65.

Macinko, J., B. Starfield and L.Y. Shi. 2007. "Quantifying the Health Benefits of Primary Care Physician Supply in the United States." International Journal of Health Services 37(1): 111-26.

Nolte, E. and C.M. McKee. 2008."Measuring the Health of Nations: Updating and Earlier Analysis." Health Affairs 27(1): 58-71.

Or, Z., J. Wang and D. Jamison. 2005. "International Differences in the Impact of Doctors on Health: A Multilevel Analysis of OECD Countries." Journal of Health Economics 24: 531-60.

Pierard, E. 2009. The Effect of Physician Supply on Health Status as Measured in the National Population Health Survey. Waterloo Economic Series. Working Paper \#09-01. Waterloo, ON: University of Waterloo.

Schoen, C., R. Osborn, S.K. How, M.M. Doty and J. Peugh. 2009 (January-February). "In Chronic Condition: Experiences of Patients with Complex Health Care Needs, in Eight Countries, 2008." Health Affairs 28(1): w1-w16.

Schoen, C., R. Osborn, P.T. Huynh, M. Doty, K. Zapert, J. Peugh and K. Davis. 2005 (JulyDecember). "Taking the Pulse of Health Care Systems: Experiences of Patients with Health Problems in Six Countries." Health Affairs (Suppl.) W5: 509-25.

Starfield, B., L.Y. Shi and J. Macinko. 2005. "Contribution of Primary Care to Health Systems and Health." Milbank Quarterly 83(3): 457-502.

Watson, D.E., S. Slade, L. Buske and J. Tepper. 2006. "Intergenerational Differences in Workloads among Primary Care Physicians: A Ten-Year, Population-Based Study." Health Affairs 25(6): $1620-28$. 